\title{
ARBUSCULAR MYCORRHIZAL SYMBIOSIS, ECOSYSTEM PROCESSES AND ENVIRONMENTAL CHANGES IN TROPICAL SOILS
}

\author{
GEOFREY SOKA ${ }^{1} *-$ MARK RITCHIE $^{2}$ \\ ${ }^{I}$ Department of Wildlife Management, Sokoine University of Agriculture, \\ P.O. Box 3073, Morogoro, Tanzania \\ (phone: +255-782-975-720) \\ ${ }^{2}$ Department of Biology, Syracuse University, \\ 107 College Place, NY 13244 USA \\ *Corresponding author \\ e-mail address: gesoka@gmail.com; \\ (Received 30th Oct 2013; accepted 14th Aug 2014)
}

\begin{abstract}
Arbuscular mycorrhizal fungi (AMF) are more widely distributed and associate with a wide range of plant species. AMF are keystone organisms that form an interface between soils and plant roots, and are sensitive to changes in soil and plant conditions. They are important microbial symbioses for plants and under conditions of P-limitation and are significant in the maintenance of soil health and fertility. AMF are crucial for the functioning of terrestrial ecosystems and plants form symbiotic interactions with AMF and colonize more than $80 \%$ of plant roots. Mycorrhizal fungi are known to influence plant diversity patterns in a variety of ecosystems globally. AMF hyphae form an extensive network in soil and length is a common parameter used to quantifying fungal hyphae. The mycelial network of AM fungi extends into the soil volume and greatly increases the surface area for uptake of immobile nutrients. Also, AM symbioses improve drought tolerance of plants and enhance tolerance of or resistance to root pathogens. Furthermore, networks of AM hyphae play a role in the formation of stable soil aggregates, building up a macroporous structure of soil that allows penetration of water and air and prevents erosion. The functioning of AMF symbiosis is mediated by direct and indirect effects of biotic and abiotic factors of the surrounding rhizosphere, community, and ecosystem. They have great potential in the restoration of disturbed land and low fertility soil. Little is known about the effects of environmental changes on AMF abundance, activity and the impact on ecosystem services. Also, we still have much to learn regarding the extent of mycorrhizal fungal diversity. It is critical to gain a clearer understanding of functional variation among AM fungal species to guide conservation and restoration efforts.
\end{abstract}

Keywords: arbuscular; mycorrhizal; symbiosis; mycelium; hyphae; soil; terrestrial ecosystem.

\section{Introduction}

Arbuscular mycorrhiza is the most ancient and widespread form (Smith and Read, 2008). Paleobotanical and molecular sequence data suggest that the first land plants formed associations with Glomalean fungi from the Glomeromycota about 460 million years ago (Redecker et al., 2000). This is estimated to be about 400 million years before the appearance of root nodule symbioses with nitrogen-fixing bacteria. Arbuscular mycorrhizal (AM) symbioses can be formed with a very wide range of plant species, as many as 250,000 (Smith and Read, 2008). Only 150-200 species of AM fungi have so far been distinguished on the basis of morphology, but DNA-based studies suggest the true diversity of these symbionts may be very much higher (Fitter, 2005; SantosGonzález et al., 2006). The symbiosis is characterized by highly branched fungal structures, arbuscules, which grow intracellularly without penetrating the host plasmalemma (Brundrett, 2004).

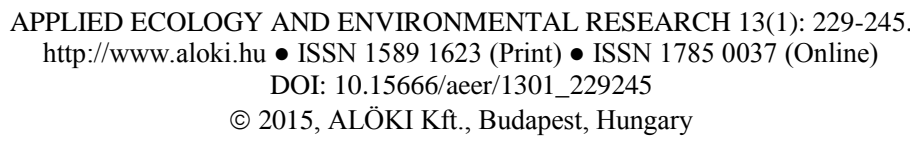


AMF are more widely distributed than other types of mycorrhizal associations (Smith and Read, 2008). They are keystone organisms that form an interface between soils and plant roots, and are sensitive to changes in soil and plant conditions (Power and Mills, 1995). They associate with a wide range of plant species (Atayese et al., 1993) and can infect most species of flowering plants in most habitats (Sieverding, 1991). AMF are important microbial symbioses for plants and under conditions of Plimitation and are significant in the maintenance of soil health and fertility, plant community development, nutrient uptake and above-ground productivity (Smith and Read, 1997). For example, Borowicz (2001) showed that plants generally grow better when they are mycorrhizal. van der Heijden et al. (1998) found that plant biodiversity, nutrient capture, and productivity in macrocosms increase significantly with increasing AM hyphal length and AMF species richness. Plants acquire nutrients and water through mycorrhizal symbioses. Numerous studies indicate that the mycorrhizal symbiosis is most important to plants when soil nutrients are limiting (Marschner and Dell, 1994; Johnson et al., 2010). Plants exchange carbon (C) for fungal phosphorus (P) and nitrogen $(\mathrm{N})$ (Smith et al., 2009). AM fungi release signaling molecules, which trigger a series of symbiotic plant genes; this actively prepares the intracellular root environment for colonization and arbuscule formation inside the root cortex (Reinhardt, 2007; Bonfante and Genre, 2008). Studies have been undertaken on the distribution and diversity of AMF species in relation to individual plant species and plant communities in farming systems (Jefwa et al., 2004), and recently there is emerging interest in the role of mycorrhizae in ecosystem processes (Rilling, 2004). Also, a few studies have tracked individual fungi through time as environments change (Hirose et al., 2004; Hu et al., 2013). Yet, these kinds of studies are necessary to understanding of the dynamics of mycorrhizal symbioses.

\section{AMF functioning and the ecosystem services}

AMF are crucial for the functioning of terrestrial ecosystems and terrestrial plants form symbiotic interactions with AMF and colonize more than $80 \%$ of plant roots (Brundrett, 2004). Mycorrhizal fungi are known to influence plant diversity patterns in a variety of ecosystems globally (Klironomos, 2002). However, the contribution of mycorrhizal fungi to the maintenance of plant diversity in the tropics is poorly known (Mcguire et al., 2008). It is well recognized that humans are changing global environments at an unprecedented rate. These changes are known to impact global climate and biota, however, the implications for communities and ecosystems are not known (IPCC, 2001). Understanding mycorrhizal responses to anthropogenic environmental changes can help predict the trajectories of future communities and ecosystems in a changing world (Yang et al., 2013; Hu et al., 2013). There is limited work undertaken in AMF at landscape level in relation to land use changes in the tropics. With increasing interference of landscape by human beings, it is vital to establish how land use changes influence AMF abundance, activity and the impact on ecosystem services. Loss of propagules of AMF will result in a decrease in the capacity of plants to take up nutrients, thus lowering soil fertility as a result the stability of the ecosystem then becomes threatened (Jeffries et al., 2003). There are a number of situations where management of the mycorrhizal symbiosis is necessary to restore plant cover, improve plant health or increase plant productivity. 
Studies carried out in agricultural systems both in tropical and temperate regions have suggested that AMF abundance may decline upon agricultural intensification (Oehl et al., 2003). Whilst reports of AM hyphal lengths in agricultural soils are becoming increasingly common (Leake et al., 2004), our knowledge of them in natural ecosystems remains scant. Knowledge about mycelial biomass is important to understand the potential roles of fungi in decomposition and nutrient cycling, and plant symbionts. For example, a study by Langley and Hungate (2003) showed that the presence of mycorrhizal fungi can alter rates of above- and below-ground litter decomposition due to chemical changes in roots and interactions with decomposer fungi. Also, at present, little is known about the control of diversity of AM fungal communities in tropical soils and, given the increasing importance attached to mycorrhizal fungal diversity for maintenance of ecosystem functioning, a better understanding of the causes of AMF diversity and its loss is clearly required.

The mycelial network of AM fungi extends into the soil volume and greatly increases the surface area for uptake of immobile nutrients, particularly $\mathrm{P}, \mathrm{N}$ and $\mathrm{Cu}$ (Brundrett, 2004; Johnson et al., 2010). Also, AM symbioses improve drought tolerance of plants and enhance tolerance of or resistance to root pathogens (Smith and Read, 1997; Auge, 2001). Furthermore, networks of AM hyphae play a role in the formation of stable soil aggregates (Cavagnaro et al., 2005), building up a macroporous structure of soil that allows penetration of water and air and prevents erosion (Rillig et al., 2002). AMF may stabilize soils up to 5 months after their host's death (Tisdall and Oades, 1980). It is also accepted that AMF receive all their carbohydrate from the host plant (Zhu and Miller, 2003; Le Tacon et al., 2013) and that the association of AMF with roots could create a sink demand for carbohydrate, which could result in up to $20 \%$ drain of carbon from the host plant and could indirectly influence carbon storage in soils (Graham, 2000). Carbon obtained by host plants can be allocated to fungal structures of functional importance to plants, AMF, or both members of the symbiosis (Olsson et al., 2002; Le Tacon et al., 2013). Allocation to fungal arbuscles and extraradical hyphae can increase plant acquisition of soil resources (Johnson et al., 2003). Fungal allocation to spores and vesicles (C storage structures) is associated with $\mathrm{C}$ accumulation by AMF (Bever et al., 2001). AM fungal diversity and activity in tropical soils have not been adequately studied and understood (Hawksworth, 2001). AMF play an important role in many ecosystems, relatively little is known about the effects of land use changes on AMF abundance and activity in tropical soils. A better understanding of the influence of land use changes on AMF abundance will facilitate their management to improve plant productivity in the poor soils. Determining the affects of land use changes on the abundance, and activity of beneficial AMF in tropical soils will be helpful in designing more sustainable management practices.

Marshner and Dell (1994) reported that the external hyphae of AMF can deliver up to $80 \%$ of a plant's $\mathrm{P}$ requirements. Understanding of the factors that enhance nutrient uptake by AMF is especially important for poor countries where the use of mineral fertilizers is not economically feasible (Johnson et al., 2010). Mycorrhizal fungi are of high value for ecosystem functioning and sustainability (Sanders, 2010). Land degradation and soil fertility depletion are considered the major threats to food security and natural resource conservation in sub-Saharan Africa (Cardoso and Kuyper, 2006). Mycorrhizal associations are complex hierarchical systems (O'Neill et al., 1991). At the core of every association is a fungus and a plant living symbiotically (Johnson et al., 1997). The functioning of this symbiosis is mediated by direct and indirect effects of 
biotic and abiotic factors of the surrounding rhizosphere, community, and ecosystem (Linderman, 1988). Also, AMF abundance may be influenced directly or indirectly by biotic interactions (Reinhard et al., 1994). Subsequently soil-borne microorganisms (i.e. fungal symbionts) may directly compete for host $\mathrm{C}$; on the other hand, they may develop a beneficial partnership in which the plant supplies $C$ and the fungus supplies the catalytic elements (Wellings et al., 1991). The benefit of mycorrhiza formation is considered to depend on the balance between the fungal demand for energy and the plant's needs for nutrients (Corrêa et al., 2011). Negative effects of mycorrhizal colonization on the host plant are expected when the net $\mathrm{C}$ costs for fungal maintenance and growth exceed the net benefits obtained from improved nutrient supply (Tuomi et al., 2001). Several studies have indicated that the effect of mycorrhiza on the host plant productivity depends on the amount of nutrients available, and on the host plant nutrient status (Cavagnaro et al., 2005; Janos, 2007).

\section{Importance of mycorrhizal mycelial networks}

AM hyphal networks impact soil structure and plant community composition and are important belowground carbon sinks (Rillig, 2004; Le Tacon et al., 2013). AMF hyphae form an extensive network in soil and length is a common parameter used to quantifying fungal hyphae (Hynes et al., 2008). Giasson et al. (2008) found that hyphae of AMF may extend $8 \mathrm{~cm}$ from the root surface. For example, in rhizosphere of Ryegrass roots, Tisdall and Oades (1979) measured about $55 \mathrm{~m}$ of hypahe per cubic centimetre of soil. Olsson et al. (1999) suggested that the mycelial network of AMF accounts for approximately half of the microbial biomass in grassland soils. For instance, it has been estimated that one gram of soil contains up to $200 \mathrm{~m}$ fungal hyphae (Leake et al., 2004). Read et al. (1976) found that it is the root-based hyphal network in soil, rather than resting spores that is responsible for infecting seedlings that become established in a natural grassland sward. Soil densities of AMF hyphae in temperate grasslands have been shown to vary with precipitation, soil fertility (Johnson et al. 2003), and plant productivity (Rillig, 2004). Hunt and Fogel (1983) reported that length of hyphae decreases with increasing soil depths. Also, there is an exponential decline in both infection and spore numbers with depth (Abbott and Robson, 1991).

Extraradical hyphal densities are important with respect to potential ecological selection for different life-history strategies under contrasting environmental conditions (Brito et al., 2011). This is because the extent of the extraradical mycelium is an important trait of AMF, affecting nutrient supply to host plants and thus probably their fitness and survival (Dodd, 2000). External AM hyphae also produce recalcitrant forms of C, such as chitin and glomalin (Zhu and Miller, 2003), and therefore might be important contributors to the structural stability of the soil and C sequestration (Zhu and Miller, 2003). Hyphal length is an important consideration that needs to be integrated into any planning for plant conservation because of the potential contribution. Despite their ubiquity and potential importance for ecosystem structure and functions, surprisingly little is known about the abundance of AM networks in tropical soils. AM hyphal length could make to plant community production and stability (Utobo et al., 2011). AMF have great potential in the restoration of disturbed land and low fertility soil (Quilambo, 2003). A more appropriate management of mycorrhizae in poor agricultural soils is expected to allow substantial reduction in the amount of mineral 
used without losses in productivity, whereas permitting a more sustainable production management.

\section{AM fungal species composition, host range and infectivity}

AM fungi vary considerably in their life histories and their affects on soil structure and plant health (Miller et al., 1995; Klironomos et al., 2000). AMF are also known to vary in their response to the mineral environment of the soil (Bever et al., 2001). For instance, it has been shown that differences in AMF species distributions are caused by habitat preferences of taxa, for example differences in tolerance to high nutrient availability (Egerton-Warburton et al., 2007; Porras-Alfaro et al., 2007), pH and soil type (Lekberg et al., 2007; Oehl et al., 2010) and mechanical disturbance (Schnoor et al., 2011). Some species of mycorrhizal fungi decline with nitrogen enrichment while others proliferate (e.g. Lilleskov et al., 2001). Wallenda and Kottke (1998) predicted that AM fungal species with a narrow host range (e.g. conifer specialists) are more adversely affected than species with a broad range of host plants. When soil phosphorus is not limiting, members of the AM fungal family Gigasporaceae are often dramatically reduced by nitrogen enrichment (Egerton-Warburton and Allen, 2000). On the other hand, when soil phosphorus is in limiting supply, nitrogen enrichment increases populations of Gigasporaceae (Eom et al., 1999). This suggests that nitrogen enrichment of phosphorus deficient soils exacerbates phosphorus limitation and increases the net benefits of mycorrhizas.

Taxa of AM fungi vary in growth rate, biomass allocation and symbiotic effects (Abbott and Robson, 1985; Miller et al., 1995). For example, Glomaceae and Acaulosporaceae allocate more biomass inside roots, and benefit their host plants through increasing pathogen resistance while Gigasporaceae allocate more biomass outside roots and are more beneficial for plant phosphorus acquisition (Klironomos et al., 2004). Brundrett et al. (1984) reported that members of the Gigasporaceae never form vesicles in plant roots, instead they form clusters of auxiliary cells in the surrounding soil (extraradical). Furthermore, the genus Gigaspora produces intra- and extraradical hyphae that are much thicker than other genera (Klironomos et al., 2000). Mycorrhizal roots on intact plants or germinated spores are best understood as sources of infective hyphae for initiating new sites of colonization of roots (Abbott and Robson, 1991). Vesicles formed within roots have been shown to act as propagules for some AM fungi (Biermann and Linderman, 1983). Extra-matrical vesicles of Gigaspora spp. represent potential propagules (Jabaji-Hare et al., 1986). For each species of fungus, types of propagules may differ widely in their tolerance of some conditions (Abbott and Robson, 1991). For example, Jasper et al. (1989) showed that hyphae of Acaulospora laevis in soil completely lost their infectivity with disturbance. Teasing apart the relationships between the environment and community composition is essential for our understanding of AMF diversity in tropical ecosystems.

\section{Influence of grazing on AMF abundance}

The abiotic environment, particularly soil fertility, water and sunlight may structure the balance of trade among symbionts (Azcon et al., 1991). The influence of grazing on soil nutrient availability and host plant productivity (Frank and McNaughton, 1993) may cause variable effects on AMF community composition and structure (Eom et al.,

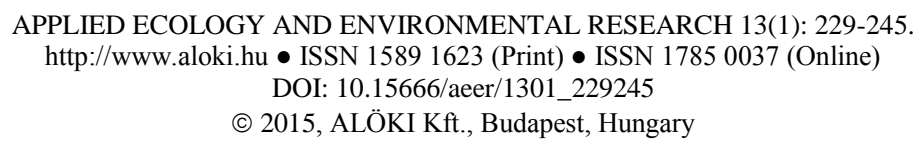


2001; Bai et al., 2013). Grazing of pasture grasses in the field has been found to affect the proportion of root length infected by decreasing root length per unit volume of soil (Trent et al., 1988; Yang et al., 2013). Grazing intensity might change the level of mycorrhizal infection in a community by altering the plant composition (Abbott and Robson, 1991). It is likely that the activity of AMF is an important factor regulating the cycling of nutrients in undisturbed ecosystems (Abbott and Robson, 1991). Because symbiotic AMF depend so heavily upon living plants for $\mathrm{C}$, they will be impacted by any process which alters belowground $C$ allocation (Frank et al., 2002). Grazing can influence the dynamics of nutrient exchange between host plants and AMF (Gehring and Whitham, 2002). Herbivore grazing can alter leaf photosynthetic rates (McNaughton 1979), aboveground production (Frank and McNaughton, 1993), and C allocation belowground (Frank et al. 2002). Allocation to AMF morphological structures can increase or decrease depending on the timing and severity of herbivory (Gange, 2007). Grazers also influence allocation to AMF morphological structures by altering soil nutrient status through direct inputs of $\mathrm{N}$ and $\mathrm{P}$ in dung and urine deposition (Schnyder et al., 2010; van der Waal et al., 2011).

\section{Effect of soil disturbance on AMF abundance and their distribution}

Disturbance can affect the occurrence of AM fungi in both agricultural and natural ecosystems. It may change the abundance and distribution of mycorrhizal fungi in several ways (Abbott and Robson, 1991). First, it may change the physical, chemical or biological environment of soil leading to either direct effects on AM fungi or indirect effects operating via effects of disturbance on plant growth. Second, disturbance may change the plant composition of the stand or eliminate host plants leading to changes in the distribution and abundance of AM fungi (Abbott and Robson, 1991). Removal of surface soil layers mainly by water erosion decreased markedly both the number of propagules of AM fungi and the extent of mycorrhiza formation (Powell, 1981; Habte, 1989). Disturbance of soil can decrease mycorrhizal infection and several factors may be responsible (Jasper et al., 1989). There may be effects of tillage on root growth affecting the extent of root colonization by mycorrhizal fungi (Borie et al., 2006). Increasing the intensity of cultivation decreased mycorrhiza formation in dry beans (Phaseolus vulgaris L.) and was apparently associated with increased soil compaction and decreased root growth (Mulligan et al., 1985). The effects of soil disturbance on the formation of mycorrhizas may be associated with decreased phosphate uptake after ploughing compared with the uptake of plants grown without tillage (O'Halloran et al., 1986).

\section{Responses of AMF abundance to environmental changes}

In the mid-1970s, it was recognized that land cover change modifies surface albedo and thus surface atmosphere energy exchanges, which have an impact on regional climate (Sagan et al., 1979). A much broader range of impacts of land use and cover change on ecosystem goods and services include impacts on biotic diversity worldwide (Sala et al., 2000), soil degradation (Trimble, 2000), and the ability of biological systems to support human needs (Vitousek et al., 1997). Land use and cover changes also determine the vulnerability of places and people to climate change (Vitousek et al., 1997; Odada et al., 2009). When aggregated globally, land use and cover changes

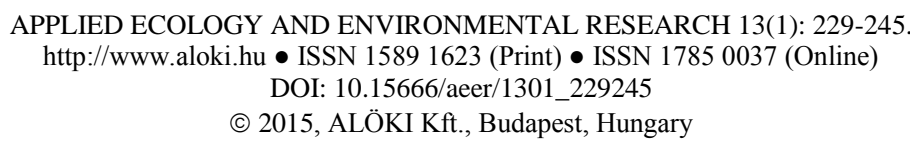


significantly affect central aspects of earth system functioning (Lambin et al., 2003). Predicting how land use changes affect land degradation, the feedback on livelihood strategies from land degradation, and the vulnerability of places and people in the face of land use and cover changes requires a good understanding of the dynamic humanenvironment interactions associated with land use change (Ramankutty and Foley, 1999).

During the last century, land use and cover have changed drastically in the tropics due to changing economy and growing population (Meyer and Turner, 1992). Natural vegetation covers have given way not only to cropland but also to pasture. Globally, concerns about the changes in land use and cover emerged due to the realization that land surface processes influence climate and that change in these processes impact ecosystem goods and services (Lambin et al., 2003). The impacts of primary concern are the negative effects of land use change on biological diversity, soil degradation and the ability of biological systems to support human needs. One way by which plants can potentially increase ecosystem productivity and stability is by forming mycorrhizal associations (van der Heijden et al., 1998; Eriksson, 2001; Hartnett and Wilson, 2002). Plants are most likely to form associations with and benefit from mycorrhizal fungi under conditions in which availability of one or more soil nutrients, including water, is low (Auge, 2001; Hoeksema and Schwartz, 2003; Jones and Smith, 2004). Tropical savanna soils have been eroded and poor in nutrients leading to reduced plant productivity (Pimentel, 2006). AMF are of particular importance to the plant in soils that are nutrient-poor (Jeffries et al., 2003; Johnson et al., 2010). Moreover, AMF may be used as sensitive indicators of ecological soil quality if they respond to environmental variation in a predictable way (Verbruggen et al., 2012).

Land use practices have placed new pressures on plant-mycorrhizal symbiosis and are evidently a threat for AMF (Siddiqui and Pichtel, 2008). Agricultural management practices might affect AMF communities both qualitatively and quantitatively (Miller et al., 1995; Cavagnaro et al., 2005; Barber et al., 2013). Studies have shown that crop rotation, fertilization, and tillage affect the composition and diversity of AMF communities as well as spore and mycelium densities in temperate and tropical agroecosystems (Jansa et al., 2002; Oehl et al., 2003). Tillage physically disrupt soil aggregates and AM hyphal networks which deteriorates soil structure, lessens fertility and nutrient cycling, and results in more $\mathrm{C}$ allocation within fungal hyphae to reestablishing these networks and less $\mathrm{C}$ to glomalin formations (Nichols and Wright, 2004). Disturbance resulting from agricultural activities has been shown to decrease AMF species richness and infectivity (Douds and Millner, 1999). In some environments, cultivation through tillage and fertilizer application has led to fewer species of AM fungi (Schenck and Kinloch, 1980). Continuous cropping with inadequate external inputs has caused depletion of nutrients such as phosphorus (P) and nitrogen (N) in tropical soils (Smithson and Giller, 2002). In no-till and reduced-tillage systems, maintenance of the integrity of the hyphal network contributes to rapid AMF infectivity and efficient nutrient uptake (Habte and Osorio, 2001; Johnson et al., 2010). Non-tillage practices along with continuous cropping system using mycorrhizal host crops, and reducing mineral fertilizers, enhance the plant-mycorrhizal symbiotic relationship (Rilling, 2004). The AMF diversity occurring over a broad range of the tropical natural systems has not yet been investigated. Studies have been done in temperate and agricultural settings (Daniell et al., 2001) but little is known about the effects of land use and cover changes in natural systems in the tropics. Information 
about species composition of AMF community appears important to understand mycorrhizal function in the ecosystems (Johnson and Pfleger, 1992). It is evident that AMF are crucial for the functioning of terrestrial ecosystems. Therefore, understanding the impact of land use and cover changes on AMF abundance in tropical soils is crucial.

\section{Effect of soil nutrients on mycorrhizal infection}

The relationships between the level of mycorrhizal colonization and soil chemical and physical properties are variable (Newman et al., 1981). High levels of infection have been observed over a wide range of soil $\mathrm{pH}$ and soil phosphate levels and (Read et al., 1976; Jeffries et al., 1988). It seems that changes in soil pH in the field will affect the proportion of colonization associated with particular fungal species but are unlikely to change the total extent of colonization (Abbott and Robson, 1991). There are, however, marked differences among species of AM fungi in the effects of soil properties on their distribution and abundance (Abbott and Robson, 1991). For example, some species of AM fungi are restricted to either acid or alkaline soils; whereas others occur in both acid and alkaline soils (Porter et al., 1987). Negative association has been found between the amounts of extractable phosphate in soils and the abundance of AM fungi as assessed by infection (Bolgiano et al., 1983; Morita and Konishi, 1989). It has been shown that some species of AM fungi differed in the extent to which phosphate decreased mycorrhiza formation (Thomson et al., 1986). AMF are also known to vary in their response to the mineral environment of the soil (Bever et al., 2001). There are critical ranges of soil-solution $\mathrm{P}$ concentration at which the host-fungus association is truly mutualistic, i.e., where the benefit each partner derives from the association outweighs the costs (Habte and Osorio, 2001; Brundret, 2004). Habte and Osorio (2001) suggested that if $\mathrm{P}$ concentration in the soil is suboptimal for mycorrhizal function, AMF symbiotic effectiveness is reduced, and the fungus and the host may compete for scarce P. When solution P concentration is much above the optimum for a given hostfungus combination, mycorrhizal colonization will be suppressed (Habte and Osorio, 2001). There is also considerable information on the negative effects of nitrogen fertilizer on mycorrhizal formation (Mosse et al., 1976). Hyphal growth tends to decrease under fertilization (Treseder, 2004).

Studies of agricultural systems have shown that high levels of fertilization can select for AMF that are less beneficial or even parasitic on their host plants (Johnson, 1993; Johnson et al., 1997). Additionally, high levels of nitrogen fertilization can decrease colonization by mycorrhizal fungi (Smith and Read, 1997) and lead to significant change in mycorrhizal community structure (Parrent and Vilgalys, 2007). The adverse effect of high soil P levels on AM formation is well documented and is mainly caused by higher P concentrations in the roots (Jasper at el., 1979; Abbott et al., 1984; Abbott and Robson, 1991). It has also been shown that high $\mathrm{P}$ levels in the soil can reduce not only spore germination and hyphal growth from the germinated spores (Miranda and Harris, 1994a) but also early colonization of the roots and growth of the extraradical mycelium (Miranda and Harris, 1994b). A comparative study across North American grasslands showed that nitrogen fertilization reduces AM hyphal densities in phosphorus rich soil, but increases AM hyphal densities when phosphorus is in limited supply (Johnson et al., 2003). Adding phosphate fertilizers has been shown either to decrease the level of mycorrhizal infection in a range of agricultural crops (George et al., 1995). For example, Nitrogen applications to wheat decreased spore numbers and 
mycorrhizal infection (Abbott and Robson, 1991). However, few studies have been made of the effects of nutrients, other than phosphorus, on the abundance and distribution of AMF in the field (Abbott and Robson, 1991).

Investigating how AMF abundance vary with changing levels of soil $\mathrm{N}$ and $\mathrm{P}$ in tropical grasslands will further advance our understanding of the factors controlling mycorrhizas because, unlike temperate grasslands, there is virtually no seasonal temperature fluctuation in tropical grasslands. Decomposition and mineralization processes are more likely to be controlled by land use, grazing pressures and seasonal moisture deficit in tropical grasslands than in temperate grasslands. There are only a few studies, however, concerning the effects of $\mathrm{P}$ on the extraradical mycelium of AM fungi, and no attempts have been made to investigate its effects on the root-soil partitioning in these fungi. Howeler et al. (1987) suggested that AM hyphae have a lower threshold for uptake of phosphorus than that of non-colonized plant roots. In soil with a high capacity to immobilize phosphorus and low available phosphate, such as many tropical soils, AM can be of great benefit to plants (George et al., 1995; Johnson et al., 2010). High phosphorus can inhibit AM colonization of plant roots, reduce formation of entry points and vesicles (Amijee et al., 1989), and decrease the length of external hyphae associated with AM (Abbott et al., 1984), consequently diminishing nutrient uptake and host benefit from AM (Schroeder and Janos, 2004).

\section{Conservation implications}

It should be apparent from the preceding discussion that Arbuscular mycorrhizal symbioses play fundamental roles in shaping plant communities and terrestrial ecosystems. The main significance of mycorrhizal fungi is that they connect the primary producers of ecosystems, plants, to the heterogeneously distributed ( $\mathrm{N}$ and $\mathrm{P}$ ) nutrients required for their growth. Mycorrhizal fungi are of high value for the ecosystem functioning and sustainability. A more appropriate management of mycorrhizae in poor soils would allow substantial reduction in the amount of mineral used without losses in productivity, whereas permitting a more sustainable production management. Studies on AMF species diversity and their functions across land use types are crucial in understanding the impact of land use changes on ecosystem services. For example, ecologists conducting field studies of the impacts of land use changes on mycorrhizal colonization and community composition could benefit from collaboration with plant physiologists to provide mechanistic insights. Currently, most studies of mycorrhizal mediation of below ground processes have examined individual plant-fungus pairs or interactions among individual mycorrhizas and biota or abiotic conditions. Although this scale of inquiry provides precise understanding of specific plant-fungal systems, it cannot provide meaningful information about mycorrhizal function within communities and ecosystems (Read and Perez-Moreno, 2003). Also, we still have much to learn regarding the extent of mycorrhizal fungal diversity. Among species of mycorrhizal fungi, there is very little knowledge of functional attributes such as stress tolerance and nutrient uptake efficiency. Comparative analysis of natural systems will improve our understanding of responses to environmental and climatic perturbations. This new knowledge is an important prerequisite for future, sustainable management of terrestrial ecosystems. It is critical to gain a clearer understanding of functional variation among AM fungal species to guide conservation and restoration efforts. 
Acknowledgements. Funding from the National Science Foundation (NSF) award No. 0842230 to Mark Richie for the work reviewed here is gratefully acknowledged. We thank Prof. Thomas R. Horton of the State University of New York College of Environmental Science and Forestry (SUNY-ESF) for many helpful discussions. The Department of Biology at Syracuse University is also acknowledged for the financial support.

\section{REFERENCES}

[1] Abbott, L.K., Robson, A.D. (1985): Formation of external hyphae in soil by four species of vesicular-arbuscular mycorrhizal fungi. - New Phytol. 99:245-255.

[2] Abbott, L.K., Robson, A.D. (1991): Factors influencing the occurrence of vesiculararbuscular Mycorrhizas. - Agric. Ecosys. and Environ. 35:121-150.

[3] Abbott, L.K., Robson, A.D., De Boer, G. (1984): The effect of phosphorus on the formation of hyphae in soil by the vesicular-arbuscular mycorrhizal fungus, Glomus fasciculatum. - New Phytol. 97:437-446.

[4] Amézketa, E. (1999): Soil aggregate stability: a review. - J. Sustain. Agric. 14:83-151.

[5] Amijee, F., Tinker, P.B., Stribley, D.P. (1989): The development of endomycorrhizal root systems. VII. A detailed study of effects of soil phosphorus on colonization. - New Phytol. 111: 435-446.

[6] Anderson, R.C., Liberta, A.E., Dickman, L.A. (1984): Interaction of vascular plants and vesicular-arbuscular mycorrhizal fungi across a soil moisture nutrient gradient. Oecologia 64:111-117.

[7] Atayese, M.O., Awotoye, O.O., Osonubi, O., Mulongo, K. (1993): Comparison of the influence of hedgerow woody legumes and cassava at the top and base of a hill slope in alley cropping system. - Biol. Fertil. Soils 16:198-204.

[8] Auge, R.M. (2001): Water relations, drought and vesicular-arbuscular mycorrhizal symbiosis. - Mycorrhiza 11:3-42.

[9] Augustine, D. J., McNaughton, S. J. (1998): Invited paper: Ungulate effects on functional species composition of plant communities: herbivore selectivity and plant tolerance. $-\mathrm{J}$. Wildlife Management 62: 1165-1183.

[10] Azcon, R., Rubio, R., Barea, J.M. (1991): Selective interactions between different species of mycorrhizal fungi and Rhizobium meliloti strains, and their effects on growth, N2fixation (N15) and nutrition of Medicago sativa L. - New Phytol. 117:399-404.

[11] Bai, G., Bao, Y., Du, G., Qi, Y. (2013): Arbuscular mycorrhizal fungi associated with vegetation and soil parameters under rest grazing management in a desert steppe ecosystem. - Mycorrhiza 23: 289-301.

[12] Barber, N.A., Kiers, E.T., Theis, N., Hazzard, R,V., Adler, L.S. (2013): Linking agricultural practices, mycorrhizal fungi, and traits mediating plant-insect interactions. Ecological Applications 23:1519-1530.

[13] Bever, J.D., Schultz, P.A., Pringle, A., Morton, J. B. (2001): Arbuscular Mycorrhizal Fungi: More Diverse than Meets the Eye, and the Ecological Tale of Why. - Bioscience 51(11): 923-932.

[14] Biermann, B., Linderman, R.G. (1983): Use of vesicular-arbuscular mycorrhizal roots, intraradical vesicles and extraradical vesicles as inoculum. - New Phytol. 95: 97-105.

[15] Bolgiano, N.C., Safir, G.R., Warncke, D.D. (1983): Mycorrhizal infection and growth of onion in the field in relation to phosphorus and water availability. - J. Am. Soc. Hortic. Sci. 108: 819-825.

[16] Bonfante, P., Genre, A. (2008): Plants and arbuscular mycorrhizal fungi: An evolutionary developmental perspective. - Trends Plant Sci. 13:492-498.

[17] Borie, F., Rubio, R., Rouanet, J.L., Morales, A., Borie, G., Rojas, C. (2006): Effects of tillage systems on soil characteristics, glomalin and mycorrhizal propagules in a Chilean Ultisol. - Soil Tillage Res. 88:253-261. 
[18] Borowicz, V. (2001): Do arbuscular mycorrhizal fungi alter plant-pathogen relations? Ecology 82:3057-3068.

[19] Brito, I., De Carvalho, M., Goss, M. J. (2011): Summer survival of arbuscular mycorrhiza extraradical mycelium and the potential for its management through tillage options in Mediterranean cropping systems. - Soil Use and Management, 27:350-356.

[20] Brundrett, M. (2004): Diversity and classification of mycorrhizal associations. - Biol. Rev. 79: 473-495.

[21] Brundrett, M.C., Piche, Y., Peterson, R.L. (1984): A new method for observing the morphology of vesicular-arbuscular mycorrhizae. - Can. J. Bot. 62: 2128-2134.

[22] Cardoso, I.M., Kuyper, T.W. (2006): Mycorrhizas and tropical soil fertility. - Agric. Ecosys. and Environ. 116(2):72-84.

[23] Cavagnaro, T.R., Jackson, L.E., Six, J., Ferris, H., Goyal, S., Asami, D., Scow, K.M. (2006): Arbuscular mycorrhizas, microbial communities, nutrient availability, and soil aggregates in organic tomato production. - Plant and Soil 282:209-225.

[24] Corrêa, A., Hampp, R., Magel, E., Martins-Loução, M. (2011): Carbon allocation in ectomycorrhizal plants at limited and optimal $\mathrm{N}$ supply: an attempt at unraveling conflicting theories. - Mycorrhiza 21(1):35-51.

[25] Daniell, T.J., Husband, R., Fitter, A.H., Young, J.P.W. (2001): Molecular diversity of arbuscular mycorrhizal fungi colonising arable crops. - FEMS Microbiology Ecology 36:203-209.

[26] Degens, B. P., Sparling, G. P., Abbott, L.K. (1994): The contribution from hyphae, roots and organic carbon constituents to the aggregation of a sandy loam under long-term clover-based and grass pastures. - European Journal of Soil Science 45:459-468.

[27] Den Herder, G., Van Isterdael, G., Beeckman, T., De Smet, I. (2010): The roots of a new green revolution. - Trends in Plant Science 15: 600-607.

[28] Dickson, S., Smith, S.E., Smith, F.A. (1999): Characterization of two arbuscular mycorrhizal fungi in symbiosis with Allium porrum: colonization, plant growth and phosphate uptake. - New Phytol. 144:163-172.

[29] Dodd, J.C. (2000): The role of arbuscular mycorrhizal fungi in agro- and natural ecosystems. - Outlook on Agriculture 29(1): 55-62.

[30] Douds, D.D., Millner, P.D. (1999): Biodiversity of arbuscular mycorrhizal fungi in agroecosystems. - Agric. Ecosys. and Environ. 74:77-93.

[31] Egerton-Warburton, L.M., Allen, E.B. (2000): Shifts in arbuscular mycorrhizal communities along an anthropogenic nitrogen deposition gradient. - Ecol. Appl. 10:484496.

[32] Egerton-Warburton, L.M., Johnson, N.C., Allen, E.B. (2007): Mycorrhizal community dynamics following nitrogen fertilization: a cross-site test in five grasslands. - Ecological Monographs 77:527-544.

[33] Eom, A.H., Harnett, D.C., Wilson, G.W.T., Figge, D.A.H. (1999): The effect of fire, mowing and fertilizer amendment on arbuscular mycorrhizas in tallgrass prairie. - Am. Midl. Nat. 142:55-70.

[34] Eom, A.H., Wilson, G.W.T., Hartnett, D.C. (2001): Effects of ungulate grazers on arbuscular mycorrhizal symbiosis and fungal community structure in tallgrass prairie. Mycologia 92:233-242.

[35] Eriksson, A. (2001): Arbuscular mycorrhiza in relation to management history, soil nutrients and plant species diversity. - Plant Ecology 155:129-137.

[36] Fitter, A.H. (2005): Darkness visible, reflections on underground ecology. - Journal of Ecology 93:231-243.

[37] Frank, D.A., McNaughton, S.J. (1993): Evidence for the promotion of aboveground grassland production by native large herbivores in Yellowstone National Park. Oecologia 96: 157-161.

[38] Frank, D.A., Kuns, M.M., Guido, D.R. (2002): Consumer control of grassland plant production. - Ecology 83:602-606.

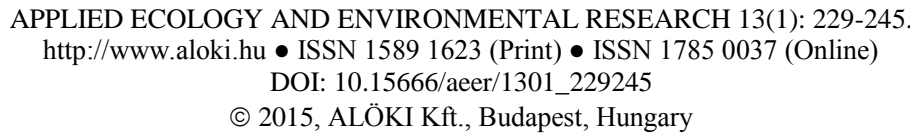


[39] Gange, A. C. (2007): Insect-mycorrhizal interactions: patterns, processes, and consequences, pp. 124-143. - In T. Ohgushi, T. P. Craig, and P. W. Price (eds.), Ecological communities: plant mediation in indirect interaction webs, Cambridge University Press, London, UK.

[40] Gehring, C.A., Whitham, T.G. (2002): Mycorrhizaeherbivore interactions: population and community consequences, pp. 295-320. - In: van der Heijden, M.G.A., Sanders, I. R. (eds.) Mycorrhizal ecology, Springer, Berlin, Germany.

[41] George, E., Marschner, H., Jakobsen, I. (1995): Role of arbuscular mycorrhizal fungi in uptake of phosphorus and nitrogen from soil. - Crit. Rev. Biotechnol. 15:257-270.

[42] Giasson, P., Karam, A., Jaouich, A. (2008): Arbuscular mycorrhizae and alleviation of soil stresses on plant growth. - In: Siddiqui, Z.A., Akhtar, M.S., Futai, K. (eds.) Mycorrhizae: sustainable agriculture and forestry, Springer and Business Media B.V. Pp. 99-134.

[43] Gorissen, A., Cotrufo, M.F. (2000): Decomposition of leaf and root tissue of three perennial grass species grown at two levels of atmospheric CO2 and $\mathrm{N}$ supply. - Plant and Soil 224:75-84.

[44] Graham, J.H. (2000): Assessing costs of arbuscular mycorrhizal symbiosis in agroecosystems. - In: Podila, G.K, Douds, Jr. D.D. (eds.) Current advances in mycorrhizae research, The American Phytopahthological Society Press, St. Paul, MN, USA, Pp. 127-140.

[45] Habte, M. (1989): Impact of simulated erosion on the abundance and activity of indigenous vesicular-arbuscular mycorrhizal endophytes in an oxisol. - Biol. Fertil. Soils 1: 164-167.

[46] Habte, M., Osorio, N.W. (2001): Arbuscular mycorrhizas: Producing and applying arbuscular mycorrhizal inoculum. - Department of Tropical Plant and Soil Sciences, College of Tropical Agriculture and Human Resources, University of Hawaii, Honolulu, HI, $47 \mathrm{p}$.

[47] Hamilton, E.W., Frank, D.A. (2001): Can plants stimulate soil microbes and their own nutrient supply? Evidence from a grazing tolerant grass. - Ecology 82:2397-2402.

[48] Hartnett, D.C., Wilson, G.W.T. (2002): The role of mycorrhizas in plant community structure and dynamics: lessons from grasslands. - Ecology 80:1187-1195.

[49] Hawksworth, D.L. (1991): The fungal dimension of biodiversity: magnitude, significance and conservation. - Mycological Research 95:641-655.

[50] Hawksworth, D.L. (2001): The magnitude of fungal diversity: the 1.5 million species estimate revisited. - Mycological Research 105:1422-1432.

[51] Hayman, D.S. (1982): Influence of soils and fertility on activity and survival of vesiculararbuscular mycorrhizal fungi. - Phytopathology 72:1119-1125.

[52] Hoeksema, J.D., Schwartz, M.W. (2003): Expanding comparative-advantage biological market models: contingency of mutualism on partners' resource requirements and acquisition trade-offs. - Proceeding of the Royal Society of London B 270:913-919.

[53] Howeler, R.H., Sieverding, E., Saif, S.R. (1987): Practical aspects of mycorrhizal technology in some tropical crops and pastures. - Plant and Soil 100:249-283.

[54] Hu, Y., Rillig, M.C., Xiang, D., Hao, Z., Chen, B. (2013): Changes of AM fungal abundance along environmental gradients in the arid and semi-arid grasslands of northern China. - PLOS ONE 8:1-10.

[55] Hunt, G.A., Fogel, R. (1983): Fungal hyphal dynamics in a western Oregon Douglas-fir stand. - Soil Biology and Biochemistry 15:641-649.

[56] Hynes, M.M., Zasoski, R.J., Bledsoe, C.S. (2008): Evaluation of two techniques for quantification of hyphal biomass. - In: Merenlender, A., McCreary, D., Purcell, K. L., (tech. eds.) Proceedings of the sixth California oak symposium: today's challenges, tomorrow's opportunities, Gen. Tech. Rep. PSW-GTR-217, Albany, CA: U.S., Department of Agriculture, Forest Service, Pacific Southwest Research Station, pp. 139148. 
[57] Intergovernmental Panel on Climate Change (IPCC) (2001): The Scientific Basis. (Houghton, J.T. , Ding, Y., Griggs, D.J., Noguer, M., van der Linden, P.J., Xiaosu, D., editors) Cambridge University Press, U.K.

[58] Jabaji-Hare, S.H., Piche, Y., Fortin, J.A. (1986): Isolation and structural characterization of soil-borne auxiliary cells of Gigaspora margarita Becker and Hall, a vesicular arbuscular mycorrhizal fungus. - New Phytol. 103: 777-784.

[59] Janos, D.P. (2007): Plant responsiveness to mycorrhizas differs from dependence upon mycorrhizas. - Mycorrhiza 17:75-91.

[60] Jansa, J., Mozafar, A., Anken, T., Ruh, R., Sanders, I.R., Frossard, E. (2002): Diversity and structure of AMF communities as affected by tillage in a temperate soil. Mycorrhiza 12:225-234.

[61] Jasper, D.A., Abbot, L.K., Robson, A.D. (1989): Hyphae of a vesicular-arbuscular mycorrhizal fungus maintain infectivity in dry soil, except when the soil is disturbed. New Phytol. 112:101-107.

[62] Jasper, D.A., Robson, A.D., Abbot, L.K. (1979): Phosphorus and the formation of vesicular-arbuscular mycorrhizal. - Soil Biology and Biochemistry 11:501-505.

[63] Jeffries, P., Gianinazzi, S., Perotto, S., Turnau, K., Barea, J.M. (2003): The contribution of arbuscular mycorrhizal fungi in sustainable maintenance of plant health and soil fertility. - Biol Fertil Soils 37:1-16.

[64] Jeffries, P., Spyropoulos, T., Vardavarkis, E. (1988): Vesicular-arbuscular mycorrhizal status of various crops in different agricultural soils of northern Greece. - Biol. Fertil. Soils 5:333-337.

[65] Jefwa, J.M. (2004): The taxonomy and Ecology of Arburscular mycorrhizal fungi (AMF) in agroforestry systems in Malawi. - PhD Thesis, University of Pretoria.

[66] Jefwa, J.M., Mwangi L.M., Odee D., Mugambi G. (2004): Preliminary studies on mycorrhizal symbiosis in plant conservation forestry and farming systems in Kenya. Journal of Tropical Microbiology 3(1):48-62.

[67] Johnson, N. C., Graham, J. H., Smith, F. A. (1997): Mycorrhizal Associations Along the Mutualism-Parasitism Continuum. - New Phytol. 135 (4): 575-586.

[68] Johnson, N.C,, Rowland, D.L., Corkidi, L., Egerton-Warburton, L., Allen, E.B. (2003): Nitrogen enrichment alters mycorrhizal allocation at five mesic to semiarid grasslands. Ecology 84:1895-1908.

[69] Johnson, N.C. (1993): Can fertilization of soil select less mutualistic mycorrhizae? - Ecol Appl. 3:749-757.

[70] Johnson, N.C., Pfleger, F.L. (1992): Vesicular-arbuscular mycorrhizae and cultural stress. - In: Bethlenfalvay, G.J., Lindennan, R.G. (eds) Mycorrhizae in Sustainable Agricullure, Am. Soc. Agron. Special PubHcalion 54, American Society of Agronomy, Madison, pp. 71-99.

[71] Johnson, N.C., Graham, J.H., Smith, F.A. (1997): Functioning of mycorrhizal associations along the mutualism-parasitism continuum. - New Phytol. 135:575-586.

[72] Johnson, N.C., Wilson, G.W.T., Bowker, M.A., Wilson, J.A., Miller, R.A. (2010): Resource limitation is a driver of local adaptation in mycorrhizal symbioses. - PNAS 107(5):2093-2098.

[73] Jones, M.D., Smith, S.E. (2004): Exploring functional definitions of mycorrhizas: are mycorrhizas always mutualisms? - Can. J. Bot. 82:1089-1109.

[74] Jonhson, N.C., Graham, J.H., Smith, F.A. ): Functioning of mycorrhizal associations along the mutualism-parasitism continuum. - New Phytol. 135:575-585

[75] Klironomos JN. (2002): Feedback with soil biota contributes to plant rarity and invasiveness in communities. - Nature 417:67-70.

[76] Klironomos, J.N., McCune, J., Moutoglis, P. (2004): Species of arbuscular mycorrhizal fungi affect mycorrhizal responses to simulated herbivory. - Applied Soil Ecology 26: 133-141. 
[77] Klironomos, J.N., McCune, J., Hart, M., Neville, J. (2000): The influence of arbuscular mycorrhizae on the relationship between plant diversity and productivity. - Ecology Letters 3:137-141.

[78] Koide, R.T. (1991): Nutrient supply, nutrient demand and plant response to mycorrhizal infection. - New Phytol. 117:365-386.

[79] Lambin, E.F., Geist, H.J., Lepers, E. (2003): Dynamics of land-use and land-cover change in tropical regions. - Annu. Rev. Environ. Resour. 28:205-241.

[80] Langley, J.A., Hungate, B.A. (2003): Mycorrhizal controls on belowground litter quality. - Ecology 84:2302-2312.

[81] Le Tacon, F., Zeller, B, Plain C, Hossann C, Bréchet C., Robin, C. (2013): Carbon Transfer from the Host to Tuber melanosporum Mycorrhizas and Ascocarps Followed Using a 13C Pulse-Labeling Technique. - PLoS ONE 8(5): e64626.

[82] Leake, J., Johnson, D., Donnelly, D., Muckle, G., Boddy, L., Read, D. (2004): Networks of power and influence: the role of mycorrhizal mycelium in controlling plant communities and agroecosystem functioning. - Can. J. Bot. 82: 1016-1045.

[83] Lekberg, Y., Koide, R.T., Rohr, J.R., Aldrich-Wolfe, L., Morton, J.B. (2007): Role of niche restrictions and dispersal in the composition of arbuscular mycorrhizal fungal communities. - Journal of Ecology 95:95-105.

[84] Lilleskov, E.A., Fahey, T.J., Lovett, G.M. (2001): Ectomycorrhizal fungal aboveground community change over an atmospheric nitrogen deposition gradient. - Ecol. Appl. 11:397-410.

[85] Linderman, R.G. (1988): Mycorrhizal interactions with the rhizosphere microflora: the mycorrhizosphere effect. - Phytopathology 78: 366-371.

[86] Mapfumo, P., Mtambanengwe, F., Giller K.E., Mpepereki, S. (2005): Tapping indigenous herbaceous legumes for soil fertility management by resource-poor farmer in Zimbabwe. - Agriculture Ecosystem and Environment 109:221-233.

[87] Marschner, H., Dell, B. (1994): Nutrient uptake in mycorrhizal symbiosis. - Plant Soil 159:89-102.

[88] McGuire, K.L., Henkel, T.W., Granzow de la Cerda, I., Villa, G., Edmund, F., Andrew, C. (2008): Dual mycorrhizal colonization of forest-dominating tropical trees and the mycorrhizal status of non-dominant tree and liana species. - Mycorrhiza 18(4): 217-222.

[89] McNaughton, S.J. (1979): Grazing as an optimization process: grass ungulate relationships in the Serengeti. - Am. Natural. 113: 691-703.

[90] Meyer, W. B., Turner II, B. L. (1992): Human population growth and global landuse/cover change. - Annu. Rev. Ecol. Syst., 23:39-61.

[91] Miller, R.M., Jastrow, J.D. (1990): Hierarchy of root and mycorrhizal fungal interactions with soil aggregation. - Soil Biology and Biochemistry 22:579-584.

[92] Miller, R.M., Reinhardt, D.R., Jastrow, J.D. (1995): External hyphal production of vesicular-arbuscular mycorrhizal fungi in pasture and tall grass prairie communities. Oecologia 103: 17-23.

[93] Miranda, J.C.C., Harris, P.J. (1994a): Effects of soil phosphorus on spore germination and hyphal growth of arbuscular mycorrhizal fungi. - New Phytol. 128:103-108.

[94] Miranda, J.C.C., Harris, P.J. (1994b): The effect of soil phosphorus on the external mycelium growth of arbuscular mycorrhizal fungi during the early stages of mycorrhiza formation. - Plant Soil 166:271-280.

[95] Morita, A., Konishi, S. (1989): Relationship between vesicular-arbuscular mycorrhizal infection and soil phosphorus concentration in tea fields. - Soil Sci. Plant Nutr. 35: 139143.

[96] Mosse, B., Powell, C. L., Hayman, D.S. (1976): Plant growth responses to vesiculararbuscular mycorrhiza. IX. Interactions between vesicular-arbuscular mycorrhiza, rock phosphate and symbiotic nitrogen fixation. - New Phytol. 76:331-342.

[97] Mulligan, M.F., Smucker, A.J.M., Safir, G.F. (1985): Tillage modifications of dry edible bean root colonization by VAM fungi. - Agron. J. 77:140-142.

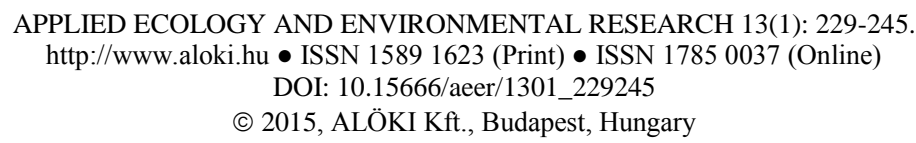


[98] Newman, E.I., Heap, A.J., Lawley, R.A. (1981): Abundance of mycorrhizas and rootsurface micro-organisms of Plantago lanceolata in relation to soil and vegetation: A multivariate approach. - New Phytol. 89: 95-108.

[99] Nichols, K.A., Wright, S.F. (2004):Contributions of soil fungi to organic matter in agricultural soils. - In: Magdoff, F.,Weil, R. (eds.) Functions and Management of Soil Organic Matter in Agro-ecosystems. CRC, Washington, DC. Pp.179-198.

[100] Odada, E.O., Ochola. W. O., Olago, D. A. (2009): Drivers of ecosystem change and their impacts on human well-being in Lake Victoria basin. - Afr. J. Ecol. 47 (1): 46-54.

[101] Oehl, F., Laczko, E., Bogenrieder, A., Stahr, K., Bösch, R., van der Heijden, M., Sieverding, E. (2010): Soil type and land use intensity determine the composition of arbuscular mycorrhizal fungal communities. - Soil Biology and Biochemistry 42:724738.

[102] Oehl, F., Sieverding, E., Ineichen, K., Mäder, P., Boller, T., Wiemken, A. (2003): Impact of land use intensity on the species diversity of arbuscular mycorrhizal fungi in agroecosystems of Central Europe. - Appl Environ Microbiol. 69:2816-2824.

[103] O'Halloran, I.P., Miller, M.H., Arnold, G. (1986): Absorption of P by corn (Zea mays L.) as influenced by soil disturbance. - Canadian Journal of Plant Science 66:287-302.

[104] Olsson, P.A., Jakobsen, I., Wallander, H. (2002): Foraging and resource allocation strategies of mycorrhizal fungi in a patchy environment. - Ecol. Stud. 157: 93-115.

[105] Olsson, P.A., Thingstrup, I., Jakobsen, I., Baath, E. (1999): Estimation of the biomass of arbuscular mycorrhizal fungi in a linseed field. - Soil Biology and Biochemistry 31: 1879-1887.

[106] Parrent, J.L., Vilgalys, R. (2007): Biomass and compositional responses of ectomycorrhizal fungal hyphae to elevated $\mathrm{CO} 2$ and nitrogen fertilization. - New Phytol. 176:164-174.

[107] Pimentel, D. (2006): Soil erosion: A food and environmental threat. - Environment, Development and Sustainability 8: 119-137.

[108] Porras-Alfaro, A., Herrera, J., Natvig, D.O., Sinsabaugh, R.L. (2007): Effect of long-term nitrogen fertilization on mycorrhizal fungi associated with a dominant grass in a semiarid grassland. - Plant and Soil 296:65-75.

[109] Porter, W.M., Robson, A.D., Abbott, L.K. (1987): Field survey of the distribution of VA mycorrhizal fungi in relation to soil pH. - J. Appl. Ecol. 24: 659-662.

[110] Powell, C.L. (1980): Mycorrhizal infectivity of eroded soil. - Soil Biology and Biochemistry 12: 247-250.

[111] Powell, C.L. (1981): Inoculation of barley with efficient mycorrhizal fungi stimulates seed yield. - Plant Soil 59: 487-489.

[112] Power, M.E., Mills, L.S. (1995): The keystone cops meet in Hilo. - Tree 10:182-184.

[113] Quilambo, O.Q. (2003): The vesicular-arbuscular mycorrhizal symbiosis. - African Journal of Biotechnology 2(12):539-546.

[114] Ramankutty, N., Foley, J.A. (1999): Estimating historical changes in global land cover: croplands from 1700 to 1992. - Glob. Biogeochem. Cycles 13(4):997-1027.

[115] Read, D.J, Koucheki, H.K., Hodgson, J. (1976): Vesicular-arbuscular mycorrhiza in natural vegetation systems. - New Phytol. 77:641-653.

[116] Read, D.J., Perez-Moreno, J.(2003): Mycorrhizas and nutrient cycling in ecosystems - a journey towards relevance? - New Phytol. 157:475-492

[117] Redecker, D., Kodner, R., Graham, L.E. (2000): Glomalean fungi from the Ordovician. Science 289:1920-1921.

[118] Reinhard, S., Weber, E., Martin, P., Marschner, H. (1994): Influence of phosphorus supply and light intensity on mycorrhizal response in Pisum-Rhizobium-Glomus symbiosis. - Experientia 50: 890-896.

[119] Reinhardt, D. (2007): Programming good relations - development of the arbuscular mycorrhizal symbiosis. - Curr Opin Plant Biol 10:98-105. 
[120] Rillig, M.C., Wright, S.F., Eviner, V.T. (2002): The role of arbuscular mycorrhizal fungi and glomalin in soil aggregation: comparing effects of five plant species. - Plant and Soil 238:325-333.

[121] Rilling, C.M. (2004): Arburscular Mycorrhizae and terrrestial ecosystem process. Ecology letters 7:740-754.

[122] Sagan, C., Toon, O.B., Pollack, J.B. (1979): Anthropogenic albedo changes and the earth's climate. - Science 206:1363-1368.

[123] Sala, O.E., Chapin, F.S., Armesto, J.J., Berlow, E., Bloomfield, J. (2000): Biodiversity global biodiversity scenarios for the year 2100. - Science 287:1770-1774

[124] Sanders, I.R. (2010): 'Designer' mycorrhizas?: Using natural genetic variation in AM fungi to increase plant growth. - ISME Journal 4:1081-1083.

[125] Santos-Gonza'lez, J.C., Finlay, R.D., Tehler, A. (2007): Seasonal dynamics of arbuscular mycorrhizal root colonization in a seminatural grassland. - Applied and Environmental Microbiology 73:5613-5623.

[126] Schenck, N.C., Kinloch, R.A. (1980): Incidence of mycorrhizal fungi on six field crops in monoculture on a newly cleared woodland site. - Mycologia 72: 445-456.

[127] Schnoor, T.K., Lekberg, Y., Rosendahl, S., Olsson, P.A. (2011): Mechanical soil disturbance as a determinant of arbuscular mycorrhizal fungal communities in seminatural grassland. - Mycorrhiza 21:211-220.

[128] Schnyder, H., Locher, F., Auerswald, K. (2010):. Nutrient redistribution by grazing cattle drives patterns of topsoil $\mathrm{N}$ and $\mathrm{P}$ stocks in a low-input pasture ecosystem. - Nutrient Cycling in Agroecosystems 88(2):183-195.

[129] Schroeder, M.S., Janos, D.P. (2004): Phosphorus and intraspecific density alter plant responses to arbuscular mycorrhizas. - Plant and Soil 264:335-348.

[130] Siddiqui, Z.A., Pichtel, J. (2008): Mycorrhixae: an overview. - In: Siddiqui, Z.A., Akhtar, M.S., Futai, K. (eds.) Mycorrhizae: Sustainable Agriculture and Forestry, Springer 1-36.

[131] Sieverding, E. (1991): Vesicular-arbuscular mycorrhiza management in tropical agro systems. - German Technical cooperation (GTZ) Eschborn, pp. 371.

[132] Smith, F.A., Grace, E.J., Smith, S.E. (2009): More than a carbon economy: Nutrient trade and ecological sustainability in facultative arbuscular mycorrhizal symbioses. - New Phytol. 182:347-358.

[133] Smith, S.E., Read, D.J. (1997): Mycorrhizal symbiosis. 2nd edition. - Academic Press, New York.

[134] Smith, S.E., Read, D.J. (2008): Mycorrhizal symbiosis. 3rd edition. - Academic Press, New York.

[135] Smithson, P.C., Giller, K.E. (2002): Appropriate farm management practices for alleviating $\mathrm{N}$ and $\mathrm{P}$ deficiencies in low-nutrient soils of the tropics. - Plant Soil 245:169180.

[136] Thomson, B.D., Robson, A.D., Abbott, L.K. (1986): Effects of Phosphorus on the formation of mycorrhizas by Gigaspora calospora and Glomus fasciculatum in relation to root carbohydrates. - New Phytol. 103:751-765.

[137] Tisdall, J. M., Oades, J. M. (1979): Stabilization of soil aggregates by the root systems of ryegrass. - Aust. J. Soil Res. 17:429-441.

[138] Tisdall, J. M., Oades, J. M. (1980): The effect of crop rotation on aggregation in a redbrown earth. - Australian Journal of Soil Research 18:423-433.

[139] Trent, J. D., Wallace, L.L. Svejcar, T.J., Christiansen, S. (1988): Effect of grazing on growth, carbohydrate pools, and mycorrhizae in winter wheat. - Canadian Journal of Plant Science 68:115-120.

[140] Treseder, K.K. (2004): A meta-analysis of mycorrhizal responses to nitrogen, phosphorus, and atmospheric CO2 in field studies. - New Phytol. 164:347-355.

[141] Trimble, S.W., Crosson, P. (2000): Land use US soil erosion rates: myth and reality. Science 289:248-50. 
[142] Tuomi, J., Kytöviita, M., Härdling, R. (2001): Cost efficiency of nutrient acquisition and the advantage of mycorrhizal symbiosis for the host plant. - Oikos 92:62-70.

[143] Utobo, E.B., Ogbodo, E.N., Nwogbaga, A.C. (2011): Techniques for Extraction and Quantification of Arbuscular Mycorrhizal Fungi. - Libyan Agriculture Research Center Journal International 2(2):68-78.

[144] Van der Heijden, M.G.A., Klironomos, J.N., Ursic, M., Moutoglis, P., Streitwolf-Engel, R., Boller, T., Wiemken, A., Sanders, I.R. (1998): Mycorrhizal fungal diversity determines plant biodiversity, ecosystem variability and productivity. - Nature 396:6972.

[145] van der Waal, C., Kool, A., Meijer, S.S., Kohi, E., Heitkönig, I.M.A., de Boer, W.F., van Langevelde, F., Grant, R.C., Peel, M.J., Slotow, R., de Knegt, H.J. Prins, H.H., de Kroon, H. (2011): Large herbivores may alter vegetation structure of semi-arid savannas through soil nutrient mediation. - Oecologia 165(4):1095-1107.

[146] Verbruggen, E., Van Der Heijden, M.G., Weedon, J.T., Kowalchuk, G.A., Röling, W.F. (2012): Community assembly, species richness and nestedness of arbuscular mycorrhizal fungi in agricultural soils. - Molecular Ecology 22:1-13.

[147] Vitousek, P.M., Mooney, H.A., Lubchenco, J., Melillo, J.M. (1997): Human domination of earth's ecosystems. - Science 277:494-499.

[148] Wallenda, T., Kottke, I. (1998): Nitrogen deposition and ectomycorrhizas. - New Phytol. 139:169-187.

[149] Wellings, N.P., Wearing, A.H., Thompson, J.P. (1991): Vesicular-arbuscular mycorrhizae (VAM) improve phosphorus and zinc nutrition and growth of pigeon pea in a Vertisol. Australian Journal of Agricultural Research 42(5):835-845.

[150] Wright, S.F., Upadhyaya, A. (1998): A survey of soils for aggregate stability and glomalin, a glycoprotein produced by hyphae of arbuscular mycorrhizal fungi. - Plant Soil 198:97-107.

[151] Yang, W., Zheng, Y., Gao, C., He, X., Ding, Q., Kim, Y., Rui, Y., Wang, S., Guo, L. (2013): The Arbuscular Mycorrhizal Fungal Community Response to Warming and Grazing Differs between Soil and Roots on the Qinghai-Tibetan Plateau. - PLOS ONE 8(9):1-11.

[152] Zhu, Y.G., Miller, R.M. (2003): Carbon cycling by arbuscular mycorrhizal fungi in soilplant systems. - Trends in Plant Science 8:407-409. 